\title{
ANALYSIS OF TAX RELIEF FOR INDIVIDUALS IN THE EUROPEAN UNION COUNTRIES
}

\author{
Eva Kolářová ${ }^{1}$ (D) \\ Blanka Jarolímová ${ }^{2}$
}

DOI: https://doi.org/10.31410/LIMEN.S.P.2019.53

\begin{abstract}
The article deals with the field of personal income tax, namely with tax relief related to personal income tax. Each country provides different reliefs and the article deals mainly with two approaches to reliefs - tax relief for taxpayer and child tax relief for working families with children. An integral part of the article is an analysis of all European Union countries in terms of these reliefs. However, it is not possible to compare the tax reliefs only based on their value, it is necessary to define important differences in terms of currency and average wages of countries and finally compare the results among themselves. The result of the article is a statistical processing of results, which determines the ranking of countries in terms of average wage and relative savings for an individual.
\end{abstract}

Keywords: Income tax, Tax payer, Tax relief.

\section{INTRODUCTION}

I

n today's global and dynamically developing world, tax policy systems are subject to constant change. In order to be able to reflect the current state of society and its various requirements, it is necessary to constantly transform and adapt. States are seeking a consensus between the level of taxation and the feasibility of tax levies for taxpayers so that they do not adversely affect their economic activity. They are looking for instruments that will not undermine the country's economic stability while ensuring the sustainability of society. The adoption of tax strategies is influenced by the political, historical and cultural context.

One of the fiscal instruments to support desirable public policies is tax relief. There are many different views to consider tax reliefs. They can be seen as an inexpensive administrative tool to support the desired public policies, or as measures that complicate the tax system and cause distortions. Their purpose is, under certain conditions, to give taxpayers an advantage in the form of lower tax levies and thereby to influence the taxpayer's behaviour in the desired direction. Tax reliefs then represent a reduction in government revenue through preferential tax treatment for specific groups of taxpayers or for specific activities. Thus, taxes in society not only fulfil a fiscal economic function, but also take into account a number of social objectives, while the extent of tax reliefs depend on the government policy objectives. The use of tax reliefs by governments is omnipresent and growing and their introduction is motivated by various economic or social objectives.

The economic importance of tax reliefs is also reflected in the EU Directive (2011/85/EU, 2011), which in its Article 14.2 obliges EU Member States to publish detailed information on the impact of tax reliefs on public revenues.

\footnotetext{
1 Tomas Bata University in Zlín, Faculty of Management and Economics, Department of Finance and Accounting, Mostní 5139, 76001 Zlín, Czech Republic

2 Tomas Bata University in Zlín, Faculty of Management and Economics, Department of Finance and Accounting, Mostní 5139, 76001 Zlín, Czech Republic
} 
However, documenting and examining the impact of tax reliefs on budget revenues is complicated because there is neither uniform international definition as such nor a uniform reporting concept, which results in complications when comparing tax reliefs internationally.

The OECD, in its publication "Tax Expenditures in OECD Countries" (OECD, 2010), states: "Tax expenditures are provisions of tax laws, regulation or practices that reduce or postpone revenue for a comparatively narrow population of taxpayers relative to a benchmark tax (Anderson, 2008). For the government, a tax expenditure is a loss of revenue; for the taxpayer it is a reduction in the tax liability. Tax expenditures are better known in many countries as tax reliefs, tax subsidies and tax aids (Schick, 2007).

According to Kraan (2004), the benchmark tax includes: the rate structure, accounting conventions, the deductibility of compulsory payments, provisions to facilitate administration, and provisions relating to international fiscal obligations, and tax expenditure are defined as a transfer of public resources that is achieved by reducing tax obligations with respect to a benchmark tax, rather than by direct expenditures.

Tax reliefs can also be defined as all those items in the existing tax forms that mean a loss of central government budget revenue because they reduce either the tax base or the tax due. This means that part of the income does not at all come into the assessment process in the form of a tax. Excepting the given items from the tax base will result in the loss of the government treasury revenue and such an item constitutes tax expenditure (Bratic, 2006).

In the absence of a generally accepted definition of a tax relief, most countries have their definition incorporated in their legal systems.

Austria defines tax reliefs as revenue foregone via preferential tax treatment benefitting private or corporate persons carrying out activities regulated by common law, which are perceived by the government as being in the public interest (CEP, 2018).

In the Netherlands, they are defined as government expenditure that comes in the form of a loss or deferment of tax receipts, resulting from a provision in the law to the extent that this provision is not in accordance with the primary structure of the tax law (OECD, 2010; CEP, 2018).

Despite criticism, different forms of tax reliefs are still being used today. On the contrary, their use has an increasing tendency. James and Nobes (2017) justify this mainly by political aspects, as tax reliefs are politically easier to enforce compared to direct government spending. Moreover, at the time of their introduction, they do not require any monetary expenditure and thus give politicians the opportunity to take various initiatives without being scrutinized by processes that are applied to budget expenditure and reveal their real costs.

The analysis should take into account that tax reliefs (expenditures) are in fact not real expenditures, they are notionally spent; they are based on assumptions and estimates of how taxpayers would behave under certain conditions. There are three possible approaches to quantification of tax reliefs (OECD, 1996; Polack's Brixi, 2004; Fookes, 2009; OECD, 2010; Kubátová and Jareš, 2011; Bratic, 2012; Burton and Sadiq, 2013): 


\section{DATA AND METHODOLOGY}

Taxation systems are diverse. Diversity does not only lie in the number of tax brackets and rates or taking into account the social aspects of the taxpayer when calculating the tax liability. Social aspects are taken into account in some countries in the form of reliefs from the tax base - taxfree allowances or, as in the Czech Republic, directly by a tax discount - credit.

As every country is specific, it is necessary to analyse the form in which tax reliefs are provided as well as the size. To be able to compare the countries mutually, only tax reliefs mentioned above are considered. To compare total tax savings, conversion to a universal currency - EURO is used. The exchange rate according to the server www.kurzy.cz was used as of December $29^{\text {th }}, 2018$.

Those countries that do not provide any tax reliefs for taxpayers or their children were not included into the comparison. Tax savings are results of either provided tax-free allowances (a taxpayer can earn a certain amount of money before paying tax) or tax credits (a taxpayer can reduce his overall tax liability). For that purpose, two formulas were stated.

Some European countries, such as the Czech Republic, Finland, Italy, Poland and Greece, provide tax reliefs in the form of tax credits. The formula to calculate the total saving per year is the following:

Tax Saving $=$ Tax Credit $/$ Average Annual Gross Income

Some European countries, such as Belgium, Estonia, Croatia, Latvia, Lithuania, Luxembourg, Germany, Slovakia, Slovenia and Spain, provide tax reliefs in the form of tax-free allowances. The formula to calculate the total saving per year is the following:

$$
\begin{aligned}
\text { Tax Saving }= & (\text { Tax-free allowance }- \text { Tax-free allowance } * \text { Tax Rate }) \\
& / \text { Average Annual Gross Income }
\end{aligned}
$$

The countries that were not considered are Bulgaria, Denmark, France, Croatia, Ireland, Cypress, Hungary, Malta, Netherland, Portugal, Romania, Sweden and Great Britain. Those countries do not provide tax reliefs for the taxpayer and children or the form provided is not applicable for the comparison.

Table 1. Tax Reliefs for a taxpayer and children in the EU countries

\begin{tabular}{|l|c|c|c|c|}
\hline & $\begin{array}{c}\text { Average Gross } \\
\text { Income Euro/ } \\
\text { Month }\end{array}$ & $\begin{array}{c}\text { Average Tax } \\
\text { Rate }\end{array}$ & Tax relief for a Taxpayer & Tax relief for kids \\
\hline Belgium & 3401 & $43.55 \%$ & $\begin{array}{c}\text { Tax-free Personal } \\
\text { Allowance }\end{array}$ & $\begin{array}{c}\text { Tax-free Children } \\
\text { Allowance }\end{array}$ \\
\hline Bulgaria & 586 & $22.01 \%$ & - & Tax Credit \\
\hline Czech Rep. & 1149 & $24.02 \%$ & Tax Credit & - \\
\hline Denmark & 5191 & $37.01 \%$ & $\begin{array}{c}\text { Tax-free Personal } \\
\text { Allowance }\end{array}$ & $\begin{array}{c}\text { Tax-free Children } \\
\text { Allowance }\end{array}$ \\
\hline Estonia & 1221 & $21.62 \%$ & Allowance & Tax Credit \\
\hline Finland & 3380 & $25.77 \%$ & - & Tax-free Children \\
\hline France & 2957 & $24.75 \%$ & Allowance \\
\hline
\end{tabular}




\begin{tabular}{|c|c|c|c|c|}
\hline Croatia & 1081 & $25.81 \%$ & $\begin{array}{c}\text { Tax-free Personal } \\
\text { Allowance }\end{array}$ & $\begin{array}{c}\text { Tax-free Children } \\
\text { Allowance }\end{array}$ \\
\hline Ireland & 3133 & $20.87 \%$ & Tax Credit & - \\
\hline Italy & 2534 & $30.62 \%$ & Tax Credit & Tax Credit \\
\hline Cyprus & 1779 & $6.80 \%$ & - & - \\
\hline Lithuania & 885 & $21.69 \%$ & $\begin{array}{c}\text { Tax-free Personal } \\
\text { Allowance }\end{array}$ & Tax Credit \\
\hline Latvia & 1013 & $27.15 \%$ & $\begin{array}{c}\text { Tax-free Personal } \\
\text { Allowance }\end{array}$ & $\begin{array}{c}\text { Tax-free Children } \\
\text { Allowance }\end{array}$ \\
\hline Luxembourg & 4412 & $28.40 \%$ & $\begin{array}{c}\text { Tax-free Personal } \\
\text { Allowance } \\
\end{array}$ & Tax Credit \\
\hline Hungary & 955 & $33.51 \%$ & (2) & $\begin{array}{c}\text { Tax-free Children } \\
\text { Allowance }\end{array}$ \\
\hline Malta & 1379 & $25.96 \%$ & - & - \\
\hline Germany & 3703 & $38.70 \%$ & $\begin{array}{c}\text { Tax-free Personal } \\
\text { Allowance }\end{array}$ & $\begin{array}{c}\text { Tax-free Children } \\
\text { Allowance }\end{array}$ \\
\hline Netherland & 2855 & $24.25 \%$ & - & - \\
\hline Poland & 1102 & $28.86 \%$ & Tax Credit & Tax Credit \\
\hline Portugal & 1158 & $20.12 \%$ & - & Tax Credit \\
\hline Austria & 3703 & $36.01 \%$ & Tax Credit & Tax Credit \\
\hline Romania & 787 & $28.21 \%$ & $\begin{array}{c}\text { Tax-free Personal } \\
\text { Allowance }\end{array}$ & \\
\hline Greece & 1092 & $16.03 \%$ & Tax Credit & Tax Credit \\
\hline Slovakia & 980 & $23.67 \%$ & $\begin{array}{c}\text { Tax-free Personal } \\
\text { Allowance }\end{array}$ & Tax Credit \\
\hline Slovenia & 1626 & $34.69 \%$ & $\begin{array}{c}\text { Tax-free Personal } \\
\text { Allowance }\end{array}$ & $\begin{array}{c}\text { Tax-free Children } \\
\text { Allowance }\end{array}$ \\
\hline Spain & 2189 & $20.10 \%$ & $\begin{array}{c}\text { Tax-free Personal } \\
\text { Allowance }\end{array}$ & $\begin{array}{c}\text { Tax-free Children } \\
\text { Allowance }\end{array}$ \\
\hline Sweden & 3340 & $23.05 \%$ & $\begin{array}{c}\text { Tax-free personal } \\
\text { Allowance }\end{array}$ & - \\
\hline Great Britain & 2498 & $20.34 \%$ & $\begin{array}{c}\text { Tax-free Personal } \\
\text { Allowance }\end{array}$ & - \\
\hline
\end{tabular}

Source: https://www.reinisfischer.com/average-salary-european-union-2018

\subsection{Hypotheses}

This research has focused on the interdependence of the data. On the basis of the data obtained, following hypotheses were stated:

Hypothesis $\mathrm{H}_{1}$ - The higher the income, the higher the tax relief for children. Hypothesis $\mathrm{H}_{2}$ - The higher the income, the higher the tax relief for a taxpayer.

\subsection{Research methods}

The basic research methods used were induction, analysis and subsequent synthesis methods. Though the research was conducted in 2019, basic statistical information was only available for the year of 2018 and previous. Basic hypotheses were set and dependencies were tested on SPSS.

Following statistical method, a regression analysis that allows us to identify and mathematically describe statistical dependencies, verify deductive theories, and help test the strength and direction of the quantified relationship, was used. Nonparametric statistical method - Spearman correlation analysis was also used. 


\section{RESULTS AND DISCUSSION}

To prove the hypotheses stated above, the survey was divided into two models. The first model considers relief for one child and the second model relief for three children.

The first mentioned shows tax reliefs for the taxpayer, a tax resident of a country, and his one child sharing a household with him. There are no other tax reliefs incorporated, even though the taxpayer would under normal circumstances qualified for them. If the tax base relief is provided, the amount of income is considered in term of tax rate.

Table 2. Total Tax Saving for a taxpayer with one child

\begin{tabular}{|c|l|c|c|c|c|}
\hline No. & $\begin{array}{c}\text { Average Gross } \\
\text { Income Euro/ } \\
\text { Month }\end{array}$ & $\begin{array}{c}\text { Tax Relief for a } \\
\text { taxpayer Euro// } \\
\text { Year }\end{array}$ & $\begin{array}{c}\text { Tax Relief } \\
\text { for one child } \\
\text { Euro/Year }\end{array}$ & $\begin{array}{c}\text { Total Tax } \\
\text { Saving }\end{array}$ \\
\hline 1. & Croatia & 1081 & 6142 & 2829 & $44.26 \%$ \\
\hline 2. & Slovakia & 980 & 3803 & 282 & $26.51 \%$ \\
\hline 3. & Spain & 2189 & 5550 & 2400 & $23.99 \%$ \\
\hline 4. & Slovenia & 1626 & 3303 & 2437 & $19.21 \%$ \\
\hline 5. & Latvia & 1013 & 912 & 2100 & $18.02 \%$ \\
\hline 6. & Germany & 3703 & 8820 & 3678 & $16.80 \%$ \\
\hline 7. & Finland & 3380 & 5279 & 1139 & $15.82 \%$ \\
\hline 8. & Greece & 1092 & 1900 & 50 & $14.88 \%$ \\
\hline 9. & Belgium & 3401 & 7070 & 1500 & $11.85 \%$ \\
\hline 10. & Austria & 3703 & 1584 & 3600 & $11.66 \%$ \\
\hline 11. & Czech Rep. & 1149 & 973 & 525 & $10.86 \%$ \\
\hline 12. & Lithuania & 885 & 2742 & 600 & $9.62 \%$ \\
\hline 13. & Estonia & 1221 & 1728 & 0 & $9.34 \%$ \\
\hline 14. & Italy & 2534 & 875 & 641 & $3.40 \%$ \\
\hline 15. & Poland & 1102 & 133 & 266 & $3.02 \%$ \\
\hline 16. & Luxembourg & 4412 & 480 & 923 & $1.61 \%$ \\
\hline
\end{tabular}

Source: own research

The second model shows tax reliefs for the taxpayer, a tax resident of a country, and his three children living in the same household. As previously stated, there are no other tax reliefs incorporated, even though the taxpayer would under normal circumstances qualified for them. If the tax base relief is provided, the amount of income is considered in term of tax rate.

Table 3. Total Tax Saving for a taxpayer with three children

\begin{tabular}{|c|l|c|c|c|c|}
\hline No. & $\begin{array}{c}\text { Average Gross } \\
\text { Income Euro/ } \\
\text { Month }\end{array}$ & $\begin{array}{c}\text { Tax Relief for a } \\
\text { taxpayer Euro/ } \\
\text { Year }\end{array}$ & $\begin{array}{c}\text { Tax Relief for } \\
\text { three children } \\
\text { Euro/Year }\end{array}$ & $\begin{array}{c}\text { Total Tax } \\
\text { Saving }\end{array}$ \\
\hline 1. & Croatia & 1081 & 6142 & 12773 & $50.42 \%$ \\
\hline 2. & Spain & 2189 & 5550 & 9100 & $44.56 \%$ \\
\hline 3. & Latvia & 1013 & 912 & 6300 & $43.22 \%$ \\
\hline 4. & Estonia & 1221 & 1728 & 5184 & $36.98 \%$ \\
\hline 5. & Lithuania & 885 & 2742 & 1800 & $33.29 \%$ \\
\hline 6. & Slovakia & 980 & 3803 & 846 & $30.18 \%$ \\
\hline 7. & Austria & 2646 & 1584 & 10800 & $27.87 \%$ \\
\hline 8. & Germany & 3703 & 8820 & 11034 & $27.39 \%$ \\
\hline 9. & Slovenia & 1626 & 3303 & 4419 & $25.85 \%$ \\
\hline 10. & Finland & 3380 & 5279 & 4002 & $22.88 \%$ \\
\hline 11. & Belgium & 3401 & 7070 & 8670 & $21.77 \%$ \\
\hline 12. & Czech Rep. & 1149 & 973 & 1997 & $21.54 \%$ \\
\hline
\end{tabular}




\begin{tabular}{|c|l|c|c|c|c|}
\hline 13. & Greece & 1092 & 1900 & 200 & $16.02 \%$ \\
\hline 14. & Poland & 1102 & 133 & 1011 & $8.65 \%$ \\
\hline 15. & Italy & 2534 & 875 & 715 & $5.23 \%$ \\
\hline 16. & Luxembourg & 4412 & 480 & 2769 & $4.39 \%$ \\
\hline
\end{tabular}

Source: own research

\subsection{Statistical data processing:}

Subsequently, data normality tests were carried out to show that, apart from income, the data did not show normal distribution. Therefore, methods of non-parametric statistics will be used, more precisely the Spearman correlation analysis.

The Spearman correlation matrix:

Table 4. The Spearman correlation matrix

\begin{tabular}{|c|c|c|c|c|}
\hline & Income & Relief & Child 1 & Child 3 \\
\hline Income & 1 & 0.068 & 0.434 & 0.541 \\
\hline Relief & 0.068 & 1 & 0.471 & 0.45 \\
\hline Child 1 & 0.434 & 0.471 & 1 & 0.761 \\
\hline Child 3 & 0.542 & 0.45 & 0.761 & 1 \\
\hline
\end{tabular}

Source: own research

It is clear from the correlation matrix that income is connected with tax relief for taxpayer rho $=0.068$, followed by relief for child with rho $=0.434$ and finally relief for three children rho $=$ 0.541 . These coefficients were found to be statistically significant.

For income and taxpayer relief is $S=633.97, p$-value $=0.8033$. Since the $p$-value is $>0.05$, the correlation coefficient may equal zero. Thus, it will be assumed that income and taxpayer relief are not related.

For the dependence of income and relief for one child, the result is $\mathrm{S}=384.78$, $\mathrm{p}$-value $=0.0929$. Since the p-value is $>0.05$, the correlation coefficient may equal zero and there is no correlation between income level and relief for one child. Thus, income and relief for one child are not related.

For the dependence of income and relief for 3 children, the result is $\mathrm{S}=256.73$, $\mathrm{p}$-value $=0.037$. Since $\mathrm{p}$-value $<0.05$, the correlation coefficient does not equal zero. Since the value of the coefficient rho $=0.541$, which indicates a moderate positive correlation, it will be further assumed, that the income and relief for 3 children are related. Thus, relief for 3 children increases with increasing income.

\section{CONCLUSION}

The article focused on the two most important income tax savings, which are considered to be relief for a taxpayer and for children. However, it has been found that countries use different ways to provide savings, and there are even countries that do not give such support at all. Therefore, each country was analysed with that regard and countries not providing these savings were excluded from the overall comparison.

All savings had to be first converted to the EURO, using the exchange rate at the end of the year 2018. Thereafter, the savings determined as tax base reliefs were first multiplied by the tax 
rate and the saving as the percentage of the average income was determined. The calculation of savings provided in the form of tax credit, i.e. directly as a deduction from tax liability, were easier to perform, when only a percentage of the average income was set.

For the subsequent assessment two models were established, namely taxpayer with one child, respectively three children.

After statistical processing in terms of solely average income, Luxembourg was the best and Croatia the worst performer. However, after comparing the two models, Croatia turned out the best. Luxembourg, that was initially favoured due to the high average income, moved down to the bottom of the table.

Tax savings for taxpayer remain the same in both models, but the savings for children change, which means that the countries strive to support taxpayers with children, i.e. the more children the taxpayer has, the higher the savings.

We assumed the validity of the hypotheses $\mathrm{H}_{1}$ and $\mathrm{H}_{2}$, but the correlation analysis shows that the hypothesis $\mathrm{H}_{1}$ can neither be confirmed nor refuted. For the model with one child we would refute the hypothesis $\mathrm{H}_{1}$, but for the model with three children we would confirm the hypothesis. On the basis of statistical results, we can also refute the hypothesis $\mathrm{H}_{2}$, as the tax relief does not depend on the taxpayer's income.

\section{ACKNOWLEDGMENTS}

This paper was supported by the Project IGA/FaME/2018/014: Influence of the specific risk factors of the financial statements on the company's competitiveness with an impact on the tax area.

\section{REFERENCES}

Anderson, B. (2008). $5^{\text {th }}$ Annual Meeting of OECD - Asia SBO, Bangkok, [online], https:// www.oecd.org/gov/budgeting/39944419.pdf

Bratic, V., (2006). Tax Expenditures: A Theoretical Review, Financial Theory and Practice, Zagreb: Institute of Public Finance, Vol. 30, No. 2, p. 113-127

Bratic, V., (2012). (In)efficiency of corporate income tax expenditures on underdeveloped areas of special tax treatment in Croatia, Financial Theory and Practice, Institute of Public Finance, Vol. 36, No. 4, p. 373-394

Burton, M. A., a Sadiq, K. (2013). Tax Expenditure Management: A Critical Assessment. Cambridge University Press, New York, [online], https://doi.org/10.1017/CBO9780511910142

Council on Economic Policies, (2018). Assessing Tax Expenditure Reporting in G20 and OECD Economies, Discussion Note 2018/3, [online], https://www.cepweb.org/wp-content/uploads/2018/11/Redonda-and-Neubig-2018.-Assessing-Tax-Expenditure-Reporting.pdf

EU Directive (2011) "2011/85/EU Directive on requirements for budgetary frameworks of the Member States", Official Journal of the EU L 36, Vol 54, pp 41-47, [online], European Parliament,https://eurlex.europa.eu/legalcontent/CS/TXT/PDF/?uri=CELEX:32011L0085\&from $=\mathrm{CS}$

Fookies, C. (2009). Spending through the Tax System: Tax Expenditures. New Zeeland Policy Perspectives Paper, [online], https://reasury.govt.nz/sites/default/files/2009-08/tpp09-01. pdf 
Kubátová, K. a Jareš, M., (2011). Identifikace a kvantifikace daňových úlev v ČR v roce 2008. Politická ekonomie Vol. 59, No. 4, [online], doi: https://doi.org/10.18267/j.polek.800

James, S. a Nobes, CH., (2017). The Economics of Taxation: Principles, policy and Practice. $17^{\text {th }}$ ed. Fiscal Publications, Birmingham, p. 341. ISBN 978-1906201357

OECD, (1996). Tax Expenditures - Recent Experiences. OECD, OECD Publishing.

OECD, (2010). Tax Expenditures in OECD Countries. OECD, OECD Publishing. ISBN 978-9264-07689-1.

Polackova Brixi, H., Christian, M. A. Valenduc a Zhicheng Li, S. (2004). Tax Expenditures-Shedding Light on Government Spending Through the Tax System. Washington: The World Bank. p. 1-3

Schick, A. (2007), "Off-Budget Expenditure: An Economic and Political Framework", OECD Journal on Budgeting, Vol. 7, No. 3, OECD, Paris. 